\title{
The Impact of State Support Measures on the Sphere of Recreation and Tourism of the Region
}

\author{
E. K. Vorobey* \\ Sochi State University, Sochi, Russia \\ *e-mail: vorobei.sochi@yandex.ru \\ Received April 30, 2021; revised May 18, 2021; accepted June 16, 2021
}

\begin{abstract}
Using the example of the Krasnodar krai, the article analyzes the mutual influence of the total financial support of the region's economy (including revenues from the state budget, Russian and foreign investments) and the tourist flow entering the region. Analysis of statistical data for the period from 2009 to 2019 showed the presence of reliable correlations between the rate of change in financial support and the rate of change in the tourist flow. Based on the identified correlations, equations are proposed that can be used to predict changes. In addition, the article shows that in the postcrisis period, a full recovery of the recreation and tourism sector requires an annual increase in the total financial flow of the Krasnodar krai by $15 \%$.
\end{abstract}

Keywords: the sphere of recreation and tourism, government support, investments, total financial support for the region's economy, tourist flow, regulatory measures, parameter correlations, regression equation

DOI: $10.1134 / \mathrm{S} 1075700721060174$

The dynamics of the tourist flow (TF) in Russian regions depends on many factors, which include: the level of income of the Russian population, which determines the material opportunities to visit the tourist regions of the country, the degree of development of the tourist infrastructure, current exchange rates, the cost of recreational and tourist services and transport links in region, as well as state support for the field of recreation and tourism through various benefits, direct and indirect subsidies, information assistance, investment in tourism infrastructure and infrastructure of related industries (transport, communications, trade, energy, etc.).

As the events of 2020 showed, unpredictable events of a global scale-pandemics, catastrophic natural phenomena, etc.- which can radically change the dynamics of TF, should be considered among the most important factors affecting tourist flows. One of the most affected sectors of the Russian economy due to the COVID-19 pandemic is the field of recreation and tourism. For example, in the Krasnodar krai, TF decreased in 2020 by more than $30 \%$ compared to the previous 2019 (from $17.3^{1}$ to $11.5^{2}$ million people).

\footnotetext{
${ }^{1}$ Report on the results for 2019 and the main activities of the Ministry of Resorts, Tourism and Olympic Heritage of the Krasnodar krai for 2020-2023, Official website of Ministry of Resorts, Tourism and Olympic legacy of Krasnodar krai. https://kurort.krasnodar.ru/activity/reports/doklady-o-rezultatakh-i-osnovnykh-napravleniyakh-deyatelnosti/56792. Accessed March 15, 2021.

2 Tourist flow to Kuban in 2020 amounted to 11.5 million tourists, TASS News Agency. https://tass.ru/obschestvo/10221085. Accessed March 15, 2021.
}

In this situation, it is nearly impossible to restore or at least stabilize the regional TF at an acceptable level without strengthening support from the state. A combination of all possible support measures, including institutional and indirect ones (such as, for example, various tax and rental benefits, targeted assistance to tourism business entities, etc.), is required. However, from our point of view, instruments of direct financial assistance to the regional economy should play a key role here: an increase in interbudgetary transfers and capital investments (including private investments within the framework of public-private partnerships).

Financial support from the budget expands the possibilities of the regions for the development of the recreational and tourism sector, allowing them to increase assistance to small and medium-sized businesses serving vacationers and tourists, to invest additional funds in the training and retraining of personnel, to provide information support, etc.

Investment activity in regions with a developed recreational and tourist sector (Krasnodar krai, Crimea, Kavminvody, etc.) also has a significant positive impact on the TF dynamics. In such regions, a significant part of investments is directed either to the creation of new and modernization of existing recreational and tourist facilities, or to the development of related industries. In addition, investments in generalpurpose infrastructure (transport routes, energy, housing and communal services, etc.) indirectly contribute to an increase in the attractiveness of the region. 
For the successful recovery of the regional sphere of recreation and tourism after the pandemic, it is necessary, first of all, to assess the need for the volume of state financial assistance and investments. Due to the high uncertainty in the market of recreational and tourist services, a clear forecast of the TF dynamics is impossible even for the short term. However, approximate forecast estimates can still be obtained if we use data on the nature of the relationship between financial and tourist flows for a sufficiently long previous period of time. Based on these estimates, it is possible to make assumptions about the amount of funding that will be required to recover the recreational and tourism sector in the region after the crisis.

The activity of the regional sphere of recreation and tourism can be assessed by various criteria; however, it is the value of TF that can be considered the main generalizing indicator reflecting the state of this sector of the economy. The value of TF directly affects the formation of a regional tourist product [1] and indirectly on the state of the regional economy as a whole (due to various multiplier effects [2,3]).

Correlation relationships between TF values and external factors influencing them have been studied quite often. In particular, in [4], an assumption was made about the existence of a relationship between the entry TF to Russia, on the one hand, and the personal income of foreign tourists, the cost of living in Russian hotels and the cost of air travel, on the other. The article [5] shows the presence of a correlation between the value of the regional TF and such factors as the cost of air travel, the size of the gross regional product, the availability of places in hotels, etc.

The paper [6] presents two types of correlations for the domestic TF of Russia: a positive correlation with the income level of domestic tourists and a negative correlation with the average price of a tour package. The article [7] revealed the presence of a moderate inverse correlation between the outbound TF from Russia and the US dollar exchange rate. In [8], a significant correlation is noted between the on-site TF and the real monetary income of the Russian population.

The article [9] shows the existence of a positive correlation between the value of the TF and the income of a particular city: the income of the city of Yeysk, Krasnodar krai, increased by $0.05 \%$ simultaneously with an increase in TF by $1 \%$.

The relationship between TF and regional economic indicators was studied in [10]. It shows the presence of two types of correlations for the gross regional product of the Republic of Karelia: a positive correlation with the outbound tourist flow (across the Karelian-Finnish border) and a negative correlation with the inbound tourist flow to the region.

The article [11] reveals a strong positive correlation (correlation coefficient 0.817 ) between the flow of foreign tourists and the financial support of the Russian tourism sector in the period from 1995 to 2018.
Of course, high values of the correlation coefficients do not always mean that there really is a significant causal relationship between phenomena, however, in many cases, assumptions about the presence of such a relationship are based on additional arguments. As world experience shows, an increase in funding for the tourism sector clearly contributes to an increase in the tourist attractiveness of the country, including for citizens of other countries. Consequently, the identification of correlations between regional economic indicators and tourist flows makes it possible to obtain quite meaningful conclusions.

The value of the tourist flow can be considered as the target indicator most suitable for solving the task at hand. First, it adequately characterizes the general state of the sphere of recreation and tourism. Secondly, the quality of TA statistics can be considered quite satisfactory. In the event that a connection between TF and financial flows entering the region really exists, equations of the mathematical model can be formed. On the basis of this model, it is possible to theoretically work out various scenarios for the development of the regional sphere of recreation and tourism with different options for state financial support and investment activity.

The work used the following methodological approach to the choice of the estimated parameters:

-The dynamics of financing of the regional economy as a whole was considered, since the sphere of recreation and tourism covers the activities of many related industries.

-Not only state financial support for the region's economy was taken into account, but also investments.

- The tourist flow entering the Krasnodar krai was considered without differentiation into domestic and foreign tourists (vacationers), since the distinction is not significant for the regional economy.

It should be noted that for the Krasnodar krai, the simultaneous accounting of state financial support and capital investments as factors affecting TF is quite justified. The overwhelming majority of investments in the krai over the past 15-20 years are in one way or another related to the development of the recreation and tourism sector. Moreover, in many respects these investments were initiated by the state, even if in form they were private. Therefore, it is obvious that the combination of enhanced budget support and a strong inflow of investments should significantly affect the size of the TF entering the region.

In the process of analysis, an attempt was made to trace the relationship between all financial flows entering the Krasnodar krai and tourist flows in the period from 2009 to 2019 . At the same time, 2020 was not included in the analysis due to the large number of uncharacteristic events generated by the COVID-19 pandemic. 
The state part of financial support can be assessed according to one of two parameters: either according to the total amount of gratuitous receipts from the federal budget [1], or according to the total amount of gratuitous receipts from the budget system as a whole, since these parameters correlate with each other (Pearson's correlation coefficient [12]: 0.996) and the difference between them is minimal, no more than $1.5 \%$ (Table 1, Fig. 1). In this article, gratuitous receipts from the budgetary system of the Russian Federation are considered as state financial support.

Total financial support (TFP) includes both public and private investments, including foreign ones. Figure 2 shows the dynamics of changes in all financial flows for the period from 2009 to 2019 in comparison with the dynamics of changes in TFs to the region for the same period. It can be seen that significant fluctuations in the amount of financial support are primarily due to fluctuations in the volume of Russian private investments entering the region, whose contribution to this value is up to $90 \%$.

The graphs in Fig. 2 demonstrate the independent behavior of TFs from changes in the values of financial flows: an almost constant growth in tourist traffic occurs against the background of both ups and downs in financing; there are no significant correlations between these parameters.

However, a comparison of the annual rate of change in financial flows with the annual rate of change in TFs shows that in two cases there are quite significant correlations. This concerns negative correlations between the rate of change in tourist flow, on the one hand, and the rate of change in TFP (Fig. 3), on the other.

The absolute values of the correlation coefficients in these two cases are about 0.8 , which is in accordance with the Chaddock scale [13, 14], which is usually used in economic research, allows one to characterize these correlations as "high" or "strong". For the rate of change of other financial parameters-receipts from the budgetary system and foreign investmentno equally strong correlations with the value of TFs were found.

Figure 4 compares the rate of TFP change in the current year with the rate of TF change in the next year (the TF curve is shifted one year back in comparison with Fig. 3).

The arrows indicate the synchronous increase (decrease) of the parameters; in the caption on the abscissa, the first year corresponds to the TFP parameter, the second to the TF parameter. Thus, for example, the rate of TFP change in 2010 and the rate of TF change in 2011, etc., are compared with each other, and the correlation coefficient between them is calculated.

It can be seen that there is a tendency for synchronous fluctuations in the curves of both parameters: the maxima of the TFP rate curve partly correspond to the maxima of the TF rate curve for the next year (the
Table 1. Gratuitous financial receipts to the budget of the Krasnodar krai from the federal budget and the budgetary system of the Russian Federation for the period from 2014 to 2019

\begin{tabular}{c|c|c}
\hline Year & $\begin{array}{c}\text { Federal budget } \\
\text { receipts, } \\
\text { billion rubles }\end{array}$ & $\begin{array}{c}\text { Receipts from the budget } \\
\text { systems of the Russian } \\
\text { Federation, billion rubles* }\end{array}$ \\
\hline 2014 & $32.239^{* *}$ & 34.015 \\
2015 & $36.247^{* * *}$ & 36.488 \\
2016 & $33.008^{* * * *}$ & 33.346 \\
2017 & $43.954^{* * * * *}$ & 44.286 \\
2018 & $40.352^{* * * * * *}$ & 40.538 \\
2019 & $47.967^{* * * * * * *}$ & 48.099 \\
\hline
\end{tabular}
of Finance of Krasnodar krai. https://minfinkubani.ru/budget_isp/regional_kons_budget.php. Accessed March 15, 2021.

** Kuban: 2014 budget execution, Open budget of Krasnodar krai: Information portal. https://openbudget23region.ru/component/attachments/download/48. Accessed March 15, 2021.

*** Kuban: 2015 budget execution, Open budget of Krasnodar krai: Information portal. https://openbudget23region.ru/component/attachments/download/353. Accessed March 15, 2021.

**** Kuban: 2016 budget execution, Open budget of Krasnodar krai: Information portal. https://openbudget23region.ru/component/attachments/download/458. Accessed March 15, 2021.

***** uban: 2017 budget execution, Open budget of Krasnodar krai: Information portal. https://openbudget23region.ru/component/attachments/download/552. Accessed March 15, 2021.

******Kuban: 2019 budget execution, Open budget of Krasnodar krai: Information portal. https://openbudget23region.ru/component/attachments/download/643. Accessed March 15, 2021.

******* Kuban: 2019 budget execution, Open budget of Krasnodar krai: Information portal. https://openbudget23region.ru/component/attachments/download/760. Accessed March 15, 2021.

same is true for the minimums on both curves). This behavior of the two compared parameters for a long time indicates that an increase in financial support for

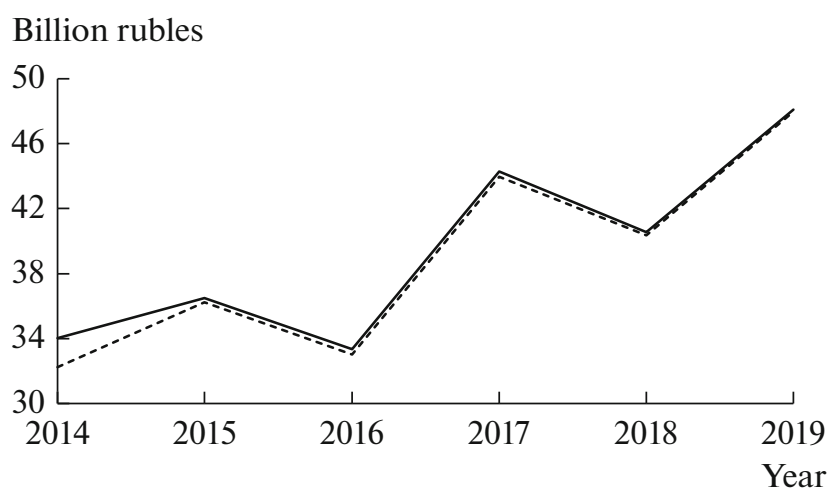

Fig. 1. Comparison of gratuitous financial receipts to the budget of the Krasnodar krai from the federal budget (---) and the budget system (-) of the Russian Federation for the period 2014-2019 (according to the Table 1). 


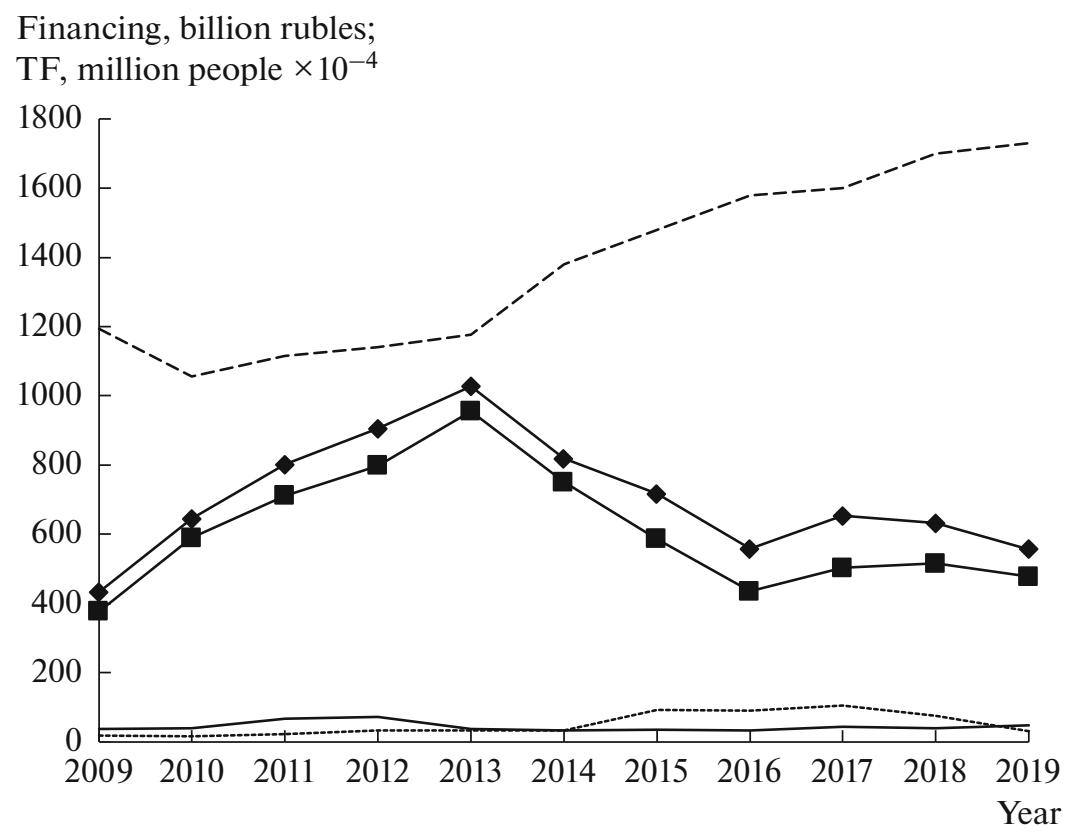

Fig. 2. Comparison of gratuitous financial receipts to the budget of the Krasnodar krai from the budgetary system (-) of the Russian Federation ${ }^{3}$, Russian investments in main capital ${ }^{4,5}(-\mathbf{-})$, foreign investment ${ }^{4,5}((---)$, in terms of the exchange rate USD for the corresponding year ${ }^{6}$ and total financial support $(--)$ with a tourist flow to the Krasnodar krai $\left.{ }^{7}\right)(---)$.

the economy and investment activity in the region may be one of the reasons for the positive growth of tourist traffic, but with a shift of one year. The calculations show that this influence is rather weak (the correlation coefficient is at the 0.1 level), i.e., changes in TF are influenced by many other factors that are not taken into account in the proposed model.

At the same time, the correlation between the TFP and TF change rates in the current year is not only strong, but also has a negative value: the correlation coefficient is at the level of -0.8 (see Fig. 3). At the same time, its absolute value does not decrease even if the TFP data for 2019 is excluded from consideration. An assumption that state financial support for the economy and investments for more than ten years has systematically caused a decrease in tourist flow seems unlikely. Therefore, the strong negative correlation of data for the same year must have other reasons.

\footnotetext{
${ }^{3}$ KK Consolidated Budget Execution Reports, Ministry of Finance of Krasnodar krai. https://minfinkubani.ru/budget_ isp/regional_kons_budget.php. Accessed March 15, 2021.

${ }^{4}$ Investments in fixed assets from all sources of financing and the inflow of foreign investments in the economy of Krasnodar krai in 2005-2016, Investment portal of Krasnodar krai. https://investkuban.ru/region/. Accessed March 15, 2021.

5 Investments in fixed assets from all sources of financing and the inflow of foreign investments in the economy of Krasnodar krai in 2017-2028, Investment portal of Krasnodar krai. https://investkuban.ru/region/. Accessed March 15, 2021.

${ }^{6}$ Dollar exchange rate over the years: Table, "Finkan" financial platform. http://fincan.ru/articles/106_kurs-dollarapo-godamtablica/. Accessed March 15, 2021.
}

According to the author, one of the most probable reasons for a strong negative correlation of the rate of change in TFP and TF in one year may be targeted actions of interested regulatory bodies to stabilize the current situation in the market of recreational and tourist services in the Krasnodar krai (which, according to the author [1], is not less than $20-25 \%$ of the regional economy). Such regulation can be expressed in an increase or decrease in the volume of financial support provided and the volume of investment in the current year as operational data on the demand for services in the field of recreation and tourism becomes available (data on hotel occupancy, the number of sold vouchers and tour packages, the number of passengers arriving in edge by air and rail, etc.). With a decrease in demand compared to the previous year, stimulating measures can be taken in the form of an increase in financing and investments, with an increase in demand, on the contrary, financing can decrease.

Since the TF is directly related to the listed indicators of activity in the field of recreation and tourism, there should be corresponding negative correlations between changes in funding and tourist flow. Indeed, with a decrease in TF towards negative values, a positive TFP growth is observed in the same year (2010, 2015, 2017; see Fig. 3). On the contrary, a positive increase in TF is accompanied by a shift in TFP

\footnotetext{
${ }^{7}$ Reports on the results and main areas of activity, Website of the Ministry of Resorts, Tourism and Olympic Heritage of Krasnodar krai. https://kurort.krasnodar.ru/activity/reports/doklady-orezultatakh-i-osnovnykh-napravleniyakh-deyatelnosti. Accessed March 15, 2021.
} 


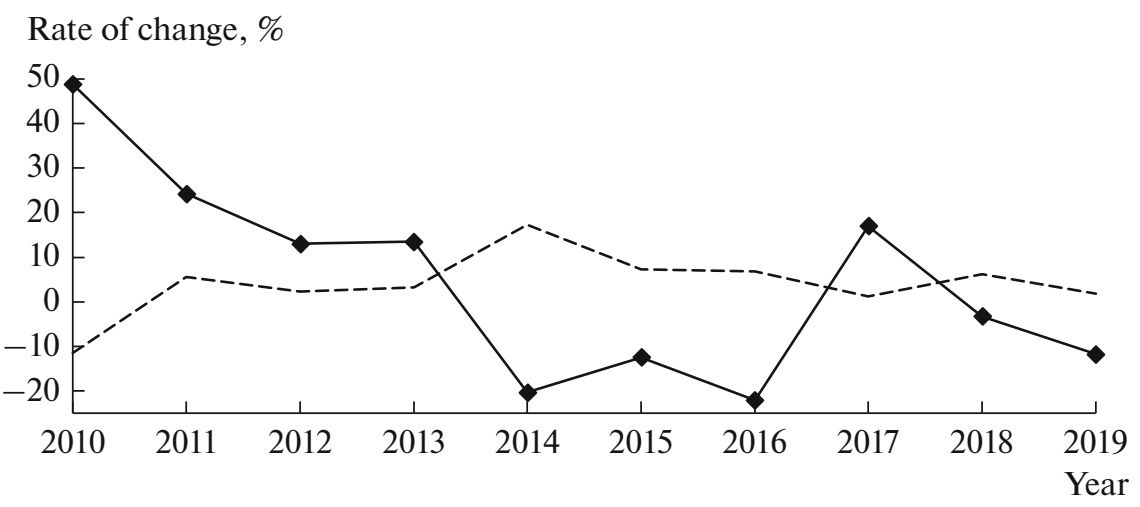

Fig. 3. The rate of change in the total financial support of the economy (- - ) of the Krasnodar krai and rate of change of tourist flow (-- ), coeff. correlation: -0.79 .

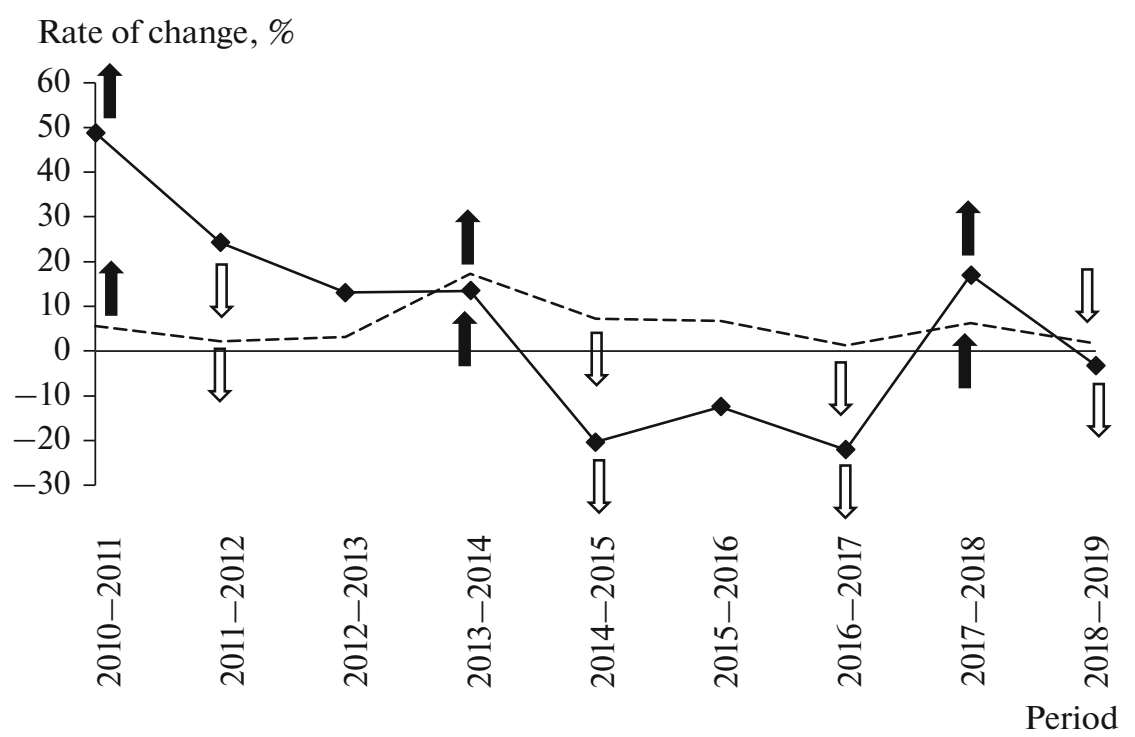

Fig. 4. Comparison of the rates of change in the total financial support of the economy of Krasnodar krai (- -$)$ in the current year (2010-2018) with the rate of change tourist flow (---) in the next year (2011-2019), coeff. correlation: 0.12.

towards negative values (2011, 2014, 2018; see Fig. 3). Thus, the revealed pattern was observed for six different years, i.e., in $60 \%$ of cases for the entire observation period from 2010 to 2019 (the exceptions are 2012, 2013, 2016 and 2019, i.e., 40\% of cases).

The reliability of the established negative correlation between the rates of changes in the TF and TFP is confirmed not only by the above theoretical considerations, but also by the data of the correlation-regression analysis performed at the significance level $\alpha=$ 0.1 . Calculated coefficient of determination $R^{2}=0.63$ shows that $63 \%$ of the total variability in the rate of change in the TFP parameter is due to fluctuations in the rate of change in the TF parameter (the causeand-effect relationship is at the level of the statistical trend). The remaining $37 \%$ of the variability in the rate of the TFP change is due to other factors that are not taken into account by the proposed model.

The influence of the rate of change in TFs of the current year (hereinafter referred to as TF') on the rate of change in TFP of the same year (designated as TFP') can be represented in the form of a linear regression equation (1), the graph of which is shown in Fig. 5.

$$
\mathrm{TFP}^{\prime}=-2.5 \mathrm{TF}^{\prime}+14.7
$$

Equation (1) shows that while the tourist flow entering the region remains unchanged compared to the previous year $\left(\mathrm{TF}^{\prime}=0\right)$, the positive increase in the total financial support from the level of the previous year is approximately $15 \%$.

Thus, the mutual influence of measures of financial support for the economy of Krasnodar krai and 
TFS', \%

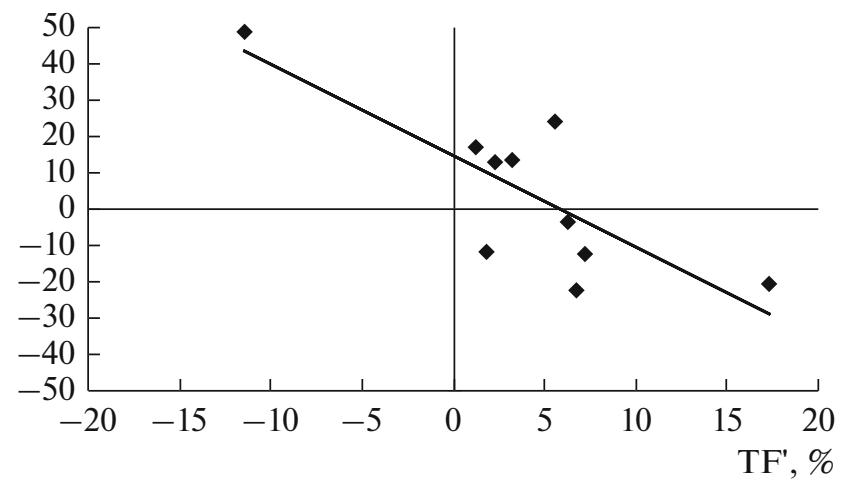

Fig. 5. The graph of the equation of the dependence of the rate of change in TFP of the economy of Krasnodar krai on the rate of change in the tourist flow; period 2010-2019, linear approximation $(-)$.

the TF can be partly explained by a combination of targeted regulatory actions and the effect of the delayed influence of the TFP' parameter of the current year on the TF parameter of the next year (Fig. 6).
Various options for regulatory actions can be preliminary (before practical implementation) estimated using the equation of the statistical trend (1). When a number of conditions are met, the approximate accuracy of such an estimate can reach $60 \%$.

As for predicting TF changes under the influence of financial support measures, the effect of the delayed influence of the TFP' parameter on the TF' parameter of the next year (see Fig. 4) cannot be statistically reliably described throughout the entire studied period due to the weak correlation between these parameters.

To establish an approximate type of dependence TF' next year $\left(\mathrm{TF}^{\prime} i+1\right)$ from TFP' current year (TFP' $i$ ), a short-term period was chosen immediately preceding the present time (from 2016 to 2019) and characterized by a high positive correlation between the parameters under consideration (Fig. 7), the reliability of which, however, cannot be strictly confirmed due to the limited amount of statistical data.

Based on the available data, a linear regression equation was formed (2), the graph of which is shown in Fig. 8.

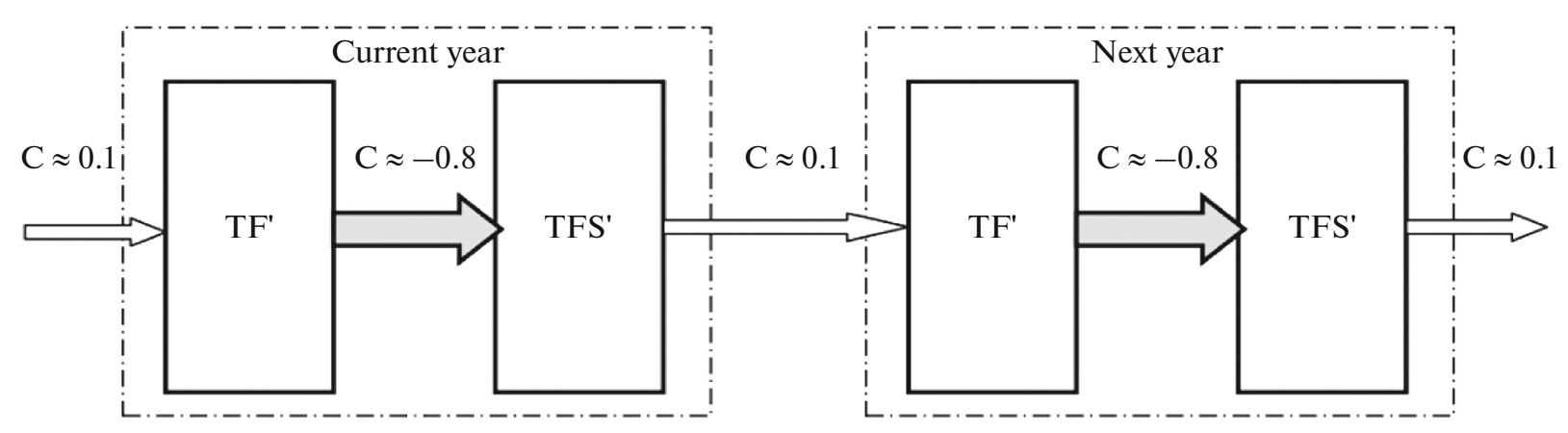

Fig. 6. Mutual influence of tourist flow parameters and total financial support ( $\mathrm{C}$ are the coefficients of correlation between the parameters).

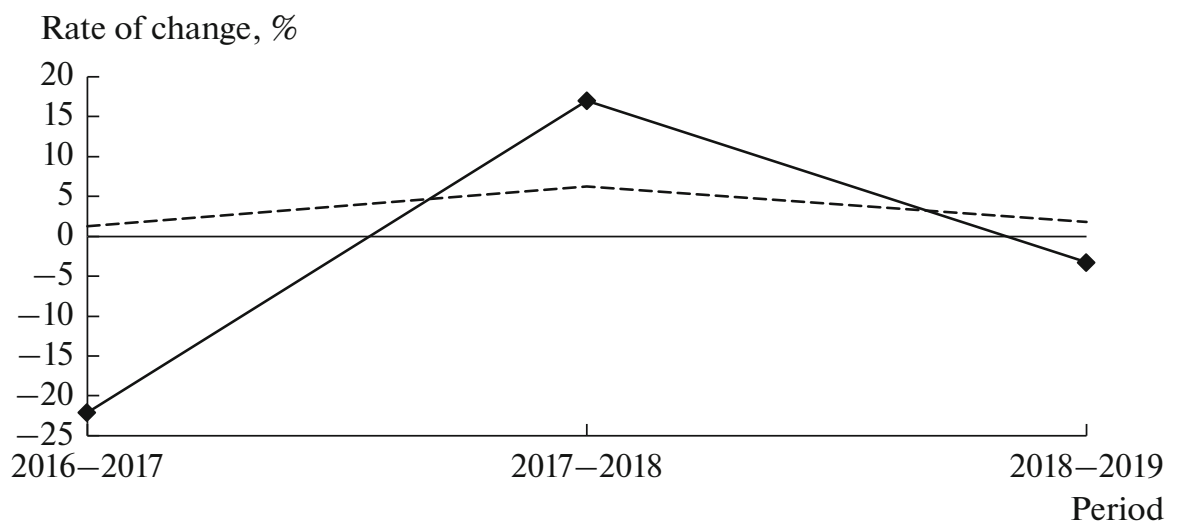

Fig. 7. Comparison of the rate of change in the amount of financial support for the economy of Krasnodar krai (- - ) in the current year (2016-2018) with the rate of change tourist flow (---) in the next year (2017-2019); coeff. correlation: 0.92 . 


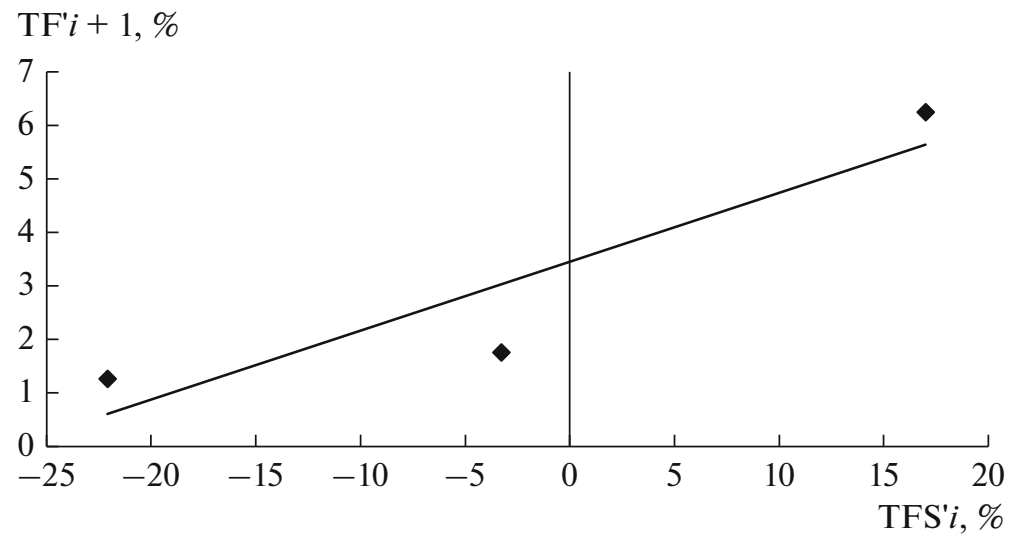

Fig. 8. The graph of the approximate equation of the dependence of the rate of change in the tourist flow in the next year (TF' $i+1)$ from the rate of change in total financial support the economy of Krasnodar krai this year (TFP' $i$ ); period 2016-2019, linear approximation.

$$
\begin{gathered}
\mathrm{TF}^{\prime} i+1=0.1 \mathrm{SFP}^{\prime} i+3.5 \\
\text { (coefficient of determination: } R^{2}=0.84 \text { ). }
\end{gathered}
$$

Equation (2) roughly shows that with the unchanged (compared to the previous year) the amount of total financial support in the current year $\left(\mathrm{TFP}^{\prime} i=0\right)$ a positive increase in the tourist flow next year from the current level $\left(\mathrm{TF}^{\prime} i+1\right)$ can be about $4 \%$. This equation can be used to a limited extent for rough predictive estimates of changes in tourist traffic depending on changes in the TFP. In this case, it is necessary to take into account the fact that the equation was formed on a small amount of statistical data (for four years) and may not reflect all the trends characteristic of the activities of the recreation and tourism sector of Krasnodar krai.

The combined application of Eqs. (1) and (2) can make it possible to evaluate the regulatory actions taken to change the TFP of Krasnodar krai, as well as predict changes in TFs depending on these actions (taking into account the limited accuracy of the estimates obtained, since both equations, and in particular Eq. (2) reflect trends rather than clear patterns).

An example of using Eqs. (1) and (2) together is shown below. According to Eq. (1), the constancy of the tourist flow $\left(\mathrm{TF}^{\prime}=0\right)$ can be ensured provided that the TFP grows annually by about $15 \%$. Maintaining at least such a rate of increase in financing over a number of years can contribute not only to the stabilization of the TF, but, according to Eq. (2), even its small increase by about $5 \%$ per year $\left(\mathrm{TFP}^{\prime} i=15 \rightarrow \mathrm{TF}^{\prime} i+1=5\right.$ ). Thus, the change in the algorithm for providing financial support from the traditional one, characterized by large periodic fluctuations in the TFP parameter (as in Fig. 3), to a new one, the essence of which is a constant positive increase in TFP (Fig. 9), provided that there are no new negative exogenous factors (pandemics, emergencies, etc.), theoretically makes it possible to achieve almost constant TF values.
It should be borne in mind that Eqs. (1) and (2) reflect the regularities of the period of a stable state of the recreation and tourism sector of the Krasnodar krai (from 2010 to 2019) and do not take into account the impact of the COVID-19 pandemic on this area (this influence could not be taken into account in this model, since in 2020 the sphere experienced an unprecedented decline. The behavior of the studied parameters this year does not correspond to the revealed correlation patterns and cannot be compared with the behavior of these parameters in a fairly stable previous period).

The data obtained allow us to conclude that it is necessary to strengthen financial support for the regional economy in the initial period of recovery in the field of recreation and tourism after the pandemic. In particular, to stabilize the tourist flow to Krasnodar krai, it can be recommended to ensure an annual positive increase in total financial support at the level of at least $15 \%$.

TFS, billion rubles;

TF, million people

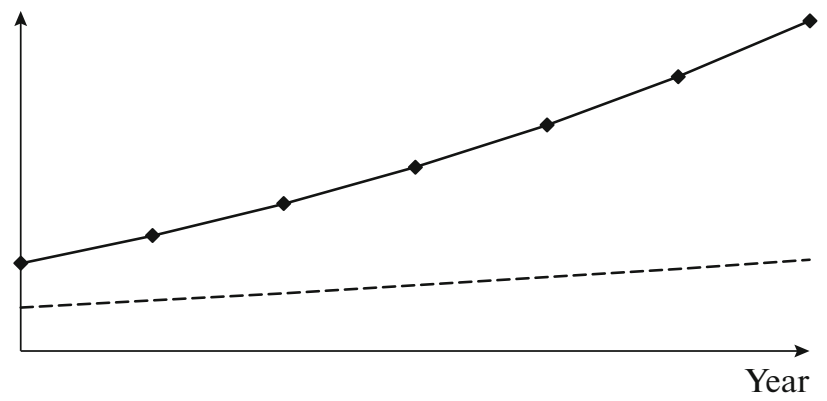

Fig. 9. Scheme of a new algorithm for the total financial support of Krasnodar krai economy (- -) (annual constant increase in total financial support: at least $15 \%$; theoretical annual increase in tourist flow (---): 5\%). 


\section{REFERENCES}

1. E. K. Vorobei, "Evaluation of the effectiveness of the functioning of the sphere of recreation and tourism of Krasnodar krai using DEA-analysis methods in the conditions of a new reality," Estestv. Gumanitarnye Issled., No. 32 (6), 94-105 (2020). https://cyberlenin$\mathrm{ka}$.ru/article/n/otsenka-effektivnosti-funktsionirovaniya-sfery-rekreatsii-i-turizma-krasnodarskogo-krayametodami-dea-analiza-v-usloviyah-novoy. Cited March 15, 2021.

2. D. B. Kuvalin, "Development of domestic tourism as a way to solve structural problems of the national economy," Vestn. Ross. Mezhdunar. Akad. Turizma, No. 2, 36-38 (2011). https://www.elibrary.ru/download/elibrary_19072122_28716256.pdf. Cited April 17, 2021.

3. E. V. Lukin, E. G. Leonidova, and M. A. Sidorov, "Stimulating domestic demand as a factor of economic growth (on the example of the domestic tourism industry)," Ekon. Sots. Peremeny: Fakty, Tendentsii, Prognoz, No. 4, 125-143 (2018). https://cyberleninka.ru/article/n/stimulirovanie-vnutrennego-sprosa-kakfaktora-ekonomicheskogo-rosta-na-primere-sferyvnutrennego-turizma. Cited April 17, 2021.

4. M. A. Bednova and T. A. Ratnikova, "Econometric analysis of demand for inbound tourism in Russia," Prikl. Ekonometrika, No. 1 (21), 97-113 (2011). https://cyberleninka.ru/article/n/ekonometricheskiyanaliz-sprosa-na-vezdnoy-turizm-v-rossii. Cited March 15, 2021.

5. A. O. Borisova, "Economic and mathematical analysis of the factors of development of inbound tourism in Russia,” Izv. Baikal. Gos. Univ., No. 4, 523-531 (2017). https://cyberleninka.ru/article/n/ekonomikomatematicheskiy-analiz-faktorov-razvitiya-vezdnogoturizma-v-rossii. Cited March 15, 2021.

6. N. A. Zyulyaev, "Econometric analysis of Russian demand for domestic tourism," Ross. Predprinimatel'stvo 18 (4), 461-470 (2017). https://cyberleninka.ru/article/n/ekonometricheskiy-analiz-sprosa-rossiyan-navnutrenniy-turizm. Cited March 15, 2021.
7. T. A. Khudyakova and I. E. Glinskikh, "Influence of fluctuations in the foreign exchange market on the state of the Russian tourism industry," Vestn. Nizhegorod. Gos. Inzh.-Ekon. Univ., No. 5 (84), 76-86 (2018). https://cyberleninka.ru/article/ n/vliyanie-kolebaniyvalyutnogo-rynka-na-sostoyanie-rossiyskoy-turisticheskoy-otrasli. Cited March 15, 2021.

8. T. V. Temyakova and N. V. Ustinova, "Econometric analysis of outbound tourist traffic from Russia," Kontsept 13, 201-205 (2015). http://e-koncept.ru/2015/85041.htm. Cited March 15, 2021.

9. A. G. Semenchenko, "Resource potential of the tourism services sector: analysis, relationships, forecast," Gumanitarnye Sots. Nauki, No. 5, 46-54 (2010). https://cyberleninka.ru/article/n/resursnyy-potentsial-turisticheskoy-sfery-uslug-analiz-vzaimosvyaziprognoz. Cited March 15, 2021.

10. E. D. Biktimirova, "Research of the process of tourism influence on the development of the Republic of Karelia," Probl. Sovrem. Ekon., No. 3 (47), 385-387 (2013). http://www.m-economy.ru/art.php?nArtId=4709. Cited March 15, 2021.

11. T. N. Grigorenko and T. V. Solod, "Assessment of the relationship between indicators of inbound tourism: An econometric approach,” Biz., Obraz., Pravo, No. 1 (46), 43-148 (2019). https://www.elibrary.ru/ item.asp?id=37023499. Cited March 15, 2021.

12. N. Draper and H. Smith, Applied Regression Analysis (Wiley, Chichester, 1981; Finansy i Statistika, Moscow, 1986).

13. I. R. Rouiga, O. N. Vladimirova, G. Y. Belyakova, et al., "Methodological aspects of the regional innovative development evaluation with focus on investment flows," Indian J. Sci. Technol. 9 (37), 1-9 (2016). https://indjst.org/articles/methodological-aspects-ofthe-regional-innovative-development-evaluationwith-focus-on-investment-flows. Cited May 22, 2021.

14. N. I. Zysman and V. V. Ilyashenko, "Influence of foreign economic factors on inflation in Russia," Izv. Ural. Gos. Ekon. Univ., No. 2 (46), 35-38 (2013). http://jne.usue.ru/download/46/5.pdf. Cited March 15, 2021. 